\title{
AN ANALYSIS OF AUTHENTIC MATERIAL USED IN TEACHING ENGLISH AT SD PURI ASAH DASAR AVESIENA GREEN SCHOOL MALANG
}

\author{
Yuhalisana Primadona. ${ }^{1}$, Santi Prastiyowati ${ }^{2}$ \\ English Language Education Department, University of Muhammadiyah Malang- Indonesia ${ }^{1}$; \\ English Language Education \\ Department, University of Muhammadiyah Malang- Indonesia ${ }^{2}$ \\ yuhalisanaprimadona@gmail.com;
}

\begin{abstract}
Authentic material is a material which is used by the purpose to imitate the real-world situations. In addition, the use of authentic material is expected to bring the learners into direct contact with a reality so the students will interest during the learning process. However, the objectives of the research were to investigate kinds of authentic material, to explore the implementation of authentic material, to find out the problem faced by the Englishteacher in using the authentic material of SD PuriAsah Dasar Avesiena Green School Malang. Descriptive qualitative research design was used in this study. The techniques in collecting the data were observation and unstructured interview while field notes and interview guide were used as the instruments. The subject of this research was an English teacher of SD PuriAsah Dasar Avesiena Green School Malang. The result of the research showed that there were forty-eight authentic materials were used in five times observations. The researcher classified those varieties of authentic materials into three kinds of authentic materials: by those forty-eight authentic materials, only one referred to Authentic Visual Material, two referred to Authentic Printed Material, and the rest forty-five referred to Realia which meant it was the most favorable Authentic Material used by the English teacher. In using the authentic material, the teacher usually conducted an outdoor class activity to find out the real object related to the topic. By seeing and holding the real thing, it made the students interested and experienced the real situation. In this case, the problem faced by the teacher was in finding the authentic material which adjusted the students' grade and topic.
\end{abstract}

Keywords: Authentic Material, Green School, Teaching, Teaching Material

\section{INTRODUCTION}

Nowadays, teaching is considered as one of the most important part of the learning process. In teaching, the role of a teacher is to help learners learn. Teachers are responsible for a large amount of what happens in the classroom such as what is taught, the resources used, the type and order of activities, classroom management, assessment, feedback, correction, and many more. It is also the part of a teacher's job to encourage learners to take responsibility for their own learning and become active learners. The quality of learning is highly dependent on students' motivation and teacher's creativity. High motivated learners who are supported by teachers, who are able to facilitate the motivation, will lead the success of achieving the target learning (Goria, Speicher, \&Stollhans, 2016). A good learning design which is supported by a good facility and

CELTIC: A Journal of Culture, English Language Teaching, Literature \& Linguistics

PISSN 2356-0401 EISSN 2621-9158

VOLUME 5 NO 22018 
creativity of teachers such as the use of teaching materials will make the learners more easily in achieving the target of learning. In other words, the presented material which does not really attract the students' interest in learning will not be able to help the students understand the lesson better (Azri\& Al-Rashdi, 2014). To decrease it, the teachers are demanded to teach effectively by using interesting media, technique or even material.

Teaching material refers to a number of resources that teacher uses to deliver instructions. However, it usually refers to concrete examples, such as worksheet or object around. Appropriate teaching materials are very important because they can significantly increase students' achievement by supporting student learning: one of the commonly use is authentic material.

According to Herod (2002), authentic learning material and activities are designed to imitate the real-world situations. In line with it, Jacobson, et.al (2009) see the authentic material as a printed material which is used in the classroom in the same way they would be used in real life. In conclusion, authentic materials are the material that can exposed the students to the real language. It can be from many things that we can find around the class. Generally, they are print, video, and audio materials that students encounter in their lives such as ATM receipt, web sites, street signs, coupons, calendars, magazines, newspapers, movies, TV programs, phone massages, radio broadcast, and so on.

As explains by Gebhard (1996), there are four kinds of authentic material such as authentic listening/viewing materials, authentic visual materials, authentic printed materials, and realia. In general, authentic materials help the students bridge the gap between the classroom and the outside world. However, it is in line with the concept of Green School.

Green School is one kind of school which frequently use the authentic material in the learning process considering its curriculum which closes to nature and mostly does an outdoor class activity. Its concept is to create a healthy and conducive environment to learn while saving energy and environmental resources. One of the advantages of a green school is it will increase the student's performances due to a lack of fresh air can reduce student concentration and cause them feel bored in paying attention.

Since English as a foreign language that is taught at school, the teacher must be able to choose and use appropriate teaching material to support their teaching so that it will make the students more interested in learning English. Departing from the background above, the researcher wants to conduct a research which concerns in the teaching material used by the teacher in teaching English.

This research takes place in SD PuriAsah Dasar Avesiena Green School Malang. It is a part of the Green School of AVESIENA Malang (SAAM), which is a school with the concept of universe-based education. Thus it is believed that the purpose of

CELTIC: A Journal of Culture, English Language Teaching, Literature \& Linguistics

PISSN 2356-0401 EISSN 2621-9158

VOLUME 5 NO 22018 
education is to accompany students to grow up. Not only able to use of what is available in nature, the students are also expected to love and maintain the natural environment. Outdoor class activity will create a fun learning atmosphere: it is expected that the students will enjoy the class and happy during the learning process.

\section{METHOD}

In conducting this research, the researcher used descriptive qualitative research design. The subject of this research was an English teacher of SD PuriAsah Dasar Avesiena Malang who used the authentic material in the learning process at the $1^{\text {st }}-5^{\text {th }}$ grade. In collecting the data, the researcher conducted non-participant observation; the researcher joined the class without any intentional interaction during the teachinglearning activity. The research has been carried out in five times observation using field notes as the instrument to help the researcher in presenting the readable data. However, semi-structured interview was conducted with the English teacher while interview guides was used as the instrument to guide the researcher to conduct the interview structurally.

\section{FINDINGS}

\section{Kinds of Authentic Material}

Based on the observation, the researcher found some Authentic Material which were used by the English teacher at the $1^{\text {st }}-5^{\text {th }}$ grade. The following table presented the Authentic Material used in teaching English at SD PuriAsah Dasar Avesiena Green School Malang.

Table1 The Kinds of Authentic Material Used at SD PuriAsah Dasar Avesiena

\begin{tabular}{|c|c|c|c|}
\hline $\begin{array}{l}\text { Observation } \\
\text { Date }\end{array}$ & Class & Topic & Authentic Material \\
\hline $\begin{array}{l}\text { October } 1^{\text {st }} \\
2018\end{array}$ & $\begin{array}{l}4^{\text {th }}- \\
\text { grade }\end{array}$ & Gardening & $\begin{array}{l}\text { Pot, broom, banana tree, orchid. printed pictures of } \\
\text { garden tools. }\end{array}$ \\
\hline $\begin{array}{l}\text { October } 2^{\text {nd }}, \\
2018\end{array}$ & $\begin{array}{l}3^{\text {rd }}- \\
\text { grade }\end{array}$ & $\begin{array}{l}\text { The Shape of } \\
\text { Thing }\end{array}$ & $\begin{array}{l}\text { Lamp, hat, cap, wallet, broom, dustbin, ruler, wallet, } \\
\text { clock, pot, teapot, statue, shoes, blackboard, whiteboard, } \\
\text { calendar, window, water, bottle, ink, pencil, pen, pencil } \\
\text { case, purse, poster, pencil sharpener, rubber, correction } \\
\text { pen, board marker, plastic, scissor, glasses, balloon. }\end{array}$ \\
\hline $\begin{array}{l}\text { October } 3^{\text {rd }} \\
2018\end{array}$ & $\begin{array}{l}1^{\text {st }}- \\
\text { grade }\end{array}$ & $\begin{array}{l}\text { The } \\
\text { Afternoon } \\
\text { Activity }\end{array}$ & $\begin{array}{l}\text { Sajadah, } \\
\text { peci, mukenah, prayer seeds, sarong }\end{array}$ \\
\hline $\begin{array}{l}\text { October } 4^{\text {th }}, \\
2018\end{array}$ & $\begin{array}{l}2^{\text {nd }}- \\
\text { grade }\end{array}$ & The Bean & Green beans, rice beans, corn beans \\
\hline
\end{tabular}

CELTIC: A Journal of Culture, English Language Teaching, Literature \& Linguistics

PISSN 2356-0401 EISSN 2621-9158

VOLUME 5 NO 22018 


\begin{tabular}{llll}
\hline $\begin{array}{l}\text { October } 5^{\text {th }}, \\
2018\end{array}$ & $\begin{array}{l}5^{\text {th }}- \\
\text { grade }\end{array}$ & Transportation & $\begin{array}{l}\text { Motorcycle, bicycle (part of bicycle: basket, pedal, } \\
\text { steering wheel). }\end{array}$ \\
\hline
\end{tabular}

Based on the Authentic Material listed, there were fouty-eight authentic material used by the teacher in teaching English at the $1^{\text {st }}-5^{\text {th }}$ grade.

\section{The Use of Authentic Material}

The topic of the first observation was about Gardening at the $4^{\text {th }}$-grade. First, teacher opened the class, and then discussed a little bit about the previous lesson. The teacher discussed about Gardening. The teacher asked "What is the meaning of gardening?" a student raised her hand then answer "berkebun." After that, the teacher asked the students to go around the school. They found banana tree. Next, they went back to the class, then the teacher sett the class into U-form so that the class circumstance conducive. The teacher took an orchid and explained its part; start from the root, stalk, leave, also the flower. Besides, the teacher took a broom and explained that the broom is also a wood product.

The second meeting was held at the $3^{\text {rd }}$-grade while the topic was about the shape of thing. The teacher opened the class first, reviewed the previous lesson and told that they will learn about the shape of thing. There are three kinds of the shape of thing: solid, liquid, and air. Next, the teacher and the students walked around the school to find out some things related to the topic. They found a lot of thing such as lamp, broom, dustbin, wallet, clock, pot, teapot, statue, shoes, blackboard, whiteboard, calendar, window, water, ink, purse, poster, rubber, board marker, printed pictures of garden tools. They discussed its shape while walking around. After that, they came back to the class. The teacher continued the explanation using the students' equipment as the example such as hat, cap, ruler, bottle, pen, pencil, pencil case, correction pen, pencil sharpener, plastic, scissor, glasses, and balloon. In the end of the lesson, they reviewed the lesson and thank to Allah for the grateful day.

The third observation was done at the $1^{\text {st }}$-grade. The topic was about the Afternoon Activity. The teacher opened the class and asked about the students' life. Next, the teacher asked what the students do in the afternoon to connect to the topic. Some students said that they are praying dhuhur. Then the teacher showed them the praying tools that have been prepared before such as sajadah, mukenah, peci, prayer seeds, and sarong. All students were excited answering the teacher's questions. Before going home, the teacher gave some questions. The one who cannot answer would go home late. This day, they spend the whole time to learn in the class.

The fourth observation have been conducted at the $2^{\text {nd }}$-grade. The topic was about the bean. It was apparently related to the Thematic lesson after the English lesson. The topic in the Thematic lesson was making mosaic from the bean, while the English

CELTIC: A Journal of Culture, English Language Teaching, Literature \& Linguistics

PISSN 2356-0401 EISSN 2621-9158

VOLUME 5 NO 22018 
lesson introduce the bean first. There were three kinds of bean that the teacher showed: green bean, rice bean, and corn beans. The teacher opened the class first and asked the students to prepare the English lesson. The teacher showed some kinds of bean, and asked the students to hold it. Students were excited during the learning process. Not only learned kinds of bean, the students also learned about the beans' color, its shape, and also count the seeds.

The last observation was done at the $5^{\text {th }}$-grade. The topic was about Transportation. Initially, the teacher opened the class and asked about the students' condition. Then, the teacher asked some questions related to the topic like what kinds of transportation they know, what kinds of transportation they usually use to go to school, and so on. Some students raise their hands to answer the question excitedly. After a few minutes brain storming, the teacher asked the students to go around the school. They looked at one of the student's bicycle and start to learn about the parts of bicycle and its functions. The teacher asked the students one by one while mentions the parts of bicycle such as basket, pedal, steer, wheel, and many more. After that, they move to the aula then the teacher gave an assignment. In the end of the lesson, the teacher asked some questions, the one who could answer fast could go home first.

\section{The Problem Faced by the English Teacher in Using Authentic Material}

Based on the interview conducted on October $13^{\text {th }}, 2018$, the teacher said that the problem in using authentic material was about arranging the lesson plan. It was about choosing what material which is appropriate with the student's grade and relate to the topic. The teacher stated that: "First, the teacher must be creative in finding the authentic material since not all objects can be used and appropriate with the student's grade. For example, the use of chair as the authentic material between small and large classes. For the first grade, it might be okay. But it will become bored for the large classes." Moreover, SD PuriAsah Dasar Avesiena Green School Malang is also an inclusive school. In every class which consists of ten to fifteen students, it consists of one to three students with special needs. Therefore, the real object was considered as the appropriate material to use since young learner like to learn from the real things they see rather than see it only on a picture or listen the teacher's explanation. It was proven by the teacher in interview section "It is more interesting rather than lecturing method. Most of students might just stay for five minutes to listen to the teacher, then they will look to other view." Additionally, the school circumstance supports him to use Authentic Material since SD PuriAsah Dasar Avesiena is a green school which the curriculum is close to nature.

\section{DISCUSSIONS}

\section{The Kinds of Authentic Material}

CELTIC: A Journal of Culture, English Language Teaching, Literature \& Linguistics PISSN 2356-0401 EISSN 2621-9158

VOLUME 5 NO 22018 
Based on the research findings, it showed that there were 48 authentic materials used by the teacher in teaching English at the 1st-5th grade of SD PuriAsah Dasar Avesiena Malang. Gebhard (1996) has classified the kinds of Authentic Material into four. Furthermore, the finding showed there are three kinds of Authentic Material used in Teaching English at SD PuriAsah Dasar Avesiena Green School Malang. They are: Authentic Visual Material, Authentic Printed Material, and Realia. By those 48 authentic materials, only one referred to Authentic Visual Material, two referred to Authentic Printed Material, and the rest forty-five referred to Realia which means it is the most favorable Authentic Material used by the English teacher.

The researcher classified the findings based on the Gebhard theory as follow:

- Authentic Visual Material: poster

- Authentic Printed Material: calendar, printed pictures of garden tools

- Realia: pot, broom, banana tree, orchid, lamp, hat, cap, wallet, broom, dustbin, ruler, wallet, o'clock, teapot, statue, shoes, blackboard, whiteboard, window, water, ink, pencil, pen, pencil case, purse, pencil sharpener, rubber, correction pen, board marker, plastic, scissor, glasses, balloon, sajadah, peci, mukenah, sarong, prayer seeds. green beans, rice beans, corn beans, bicycle, motorcycle.However, the Authentic Listening-Viewing Material did not find since SD PuriAsah Dasar Avesiena is a Green School which is mostly learning activities are involving surrounding object and nature. The finding was actually appropriate with the concept of green school that mostly does an outdoor class activity, and utilize the nature.

\section{The Useof Authentic Material}

In applying the Authentic Material, the teacher always started the class by praying, then reviewed the previous lesson, and attracted the students' interest by asking their health, their activities, and so on. In a first few minutes, the teacher usually discussed a little bit about the topic. After that, the teacher and the students walked around the school to find out the real object related with the topic. By seeing and holding the real thing, it makes the students interest and experience the real situation. It supports the theory of Heitler (2005) who mentioned that Authentic Material bring learners into direct contact with a reality. Inaddition, Green School makes children not glued to the theory only, because they can also learn and experience knowledge from nature.

\section{The Problem Faced by the English Teacher in Using Authentic Material}

Green Schools are also usually an inclusive school (Suhendi, 2011). It was one of the problems faced by the teacher of SD PuriAsah Dasar Avesiena Green School Malang about how to present the lessons well for both the regular students and the students with special needs. Furthermore, the use of Authentic Material was expected to

CELTIC: A Journal of Culture, English Language Teaching, Literature \& Linguistics 
make the students interest and easy in achieving the target of learning. It was a challenge for the teacher to find the appropriate authentic material according to the topic and the students' grade. However, the finding did not prove the theory of Tamo who mentioned: 1) Authentic Material takes much efforts and times to prepare. 2) Authentic Material containing difficult language and difficult vocab. 3) Authentic Material contains unfamiliar content. 4) Authentic Material were culturally biased.

It might be because the topic for elementary students were not that too complicated so it effected the use of the teaching material. Furthermore, the school environment supports the teacher to use the surrounding objects as the teaching material. However, the theory of green school proved that the kids are learning more when they are involved in open-class situation.

\section{CONCLUSION}

Based on the result of the research, the researcher found kinds of authentic material, how the use of authentic material, and the problem faced by the teacher in using the authentic material at SD PuriAsah Dasar Avesiena Green School Malang. Based on the findings of the research, the researcher concluded that the teacher used three kinds of authentic material in teaching English at the $1^{\text {st }}-5^{\text {th }}$ grade namely authentic visual material, authentic printed material, and realia.

In using authentic material, the teacher utilized the school environment where SD PuriAsah Dasar Avesiena Green School Malang really supports the use of the authentic material itself. The teacher usually started the lesson inside the classroom, gave some explanations then continued the lesson outside the classroom. In outdoor class activity, they found some things related to the topic. Its aims were to make the students experience the learning fun and easy to memorize the lesson. After that, they moved back to the class, closed lesson that usually ended with quick questions or reviewed the material.

A problem sometimes found by the teacher in using the authentic material. The problem was about in finding the appropriate material adjusted the students' grade and the topic. However, SD PuriAsah Dasar Avesiena Malang is a green school that also inclusive school. In the class which consist of ten to fifteen students, one to three of them were students with special needs. It was another teacher's challenge to teach both regular and students with special needs easy and fun by utilized the authentic material.

\section{REFERENCES}

Azri, R. H. Al, \& Al-Rashdi, M. H. (2014). The effect of using authentic materials in teaching. International Journal of Scientific \& Technology Research, 3(10), 249254.

CELTIC: A Journal of Culture, English Language Teaching, Literature \& Linguistics

PISSN 2356-0401 EISSN 2621-9158

VOLUME 5 NO 22018 
Gebhard, J. G. (1996). Teaching English as a Foreign or Second Language: A Teacher Self-Development and Methodology Guide, 280.

Goria, C., Speicher, O., \&Stollhans, S. (2016). Innovative language teaching and learning at university: enhancing participation and collaboration. United Kingdom: Research-publishing.net.

Heitler, D. (2005). Teaching With Authentic Materials. Encuentro, 6(2), 10(7). https://doi.org/10.3126/nelta.v11i1.3132

Herod, L. (2002). Adult Learning: from Theory to Practice.

Jacobson, D. et. al. (2009). Methods for Teaching. United States: Pearson.

Suhendi. (2011). Belajar Bersama Alam. SoU Publisher.

Tamo, D. (2009). The Use of Authentic Materials in Classrooms. Lcpj, 2(1991), 74-78. 